\title{
THE STRUCTURE, DEGRADATION AND FIBRE DRAWING PROPERTIES OF PHOSPHATE BASED GLASSES FIBRE: THE EFFECTS OF $\mathrm{Fe}_{2} \mathrm{O}_{3}$ and $\mathrm{B}_{2} \mathrm{O}_{3}$ ADDITION
}

\author{
CHENKAI ZHU*,**, JINSONG LIU***, SONGLIN HUANG***, CHRIS RUDD*,**, \#XIAOLING LIU*,** \\ *Ningbo Nottingham International Academy for the Marine Economy and Technology, \\ The University of Nottingham Ningbo China, Ningbo, 315100, China \\ **Ningbo Nottingham New Materials Institute, The University of Nottingham Ningbo China, Ningbo, 315100, China \\ ***Department of Technology, Sinoma Co., Ltd.,198 Tongtian Road, Nanjing, 211100, China \\ "E-mail: Xiaoling.Liu@nottingham.edu.cn
}

Submitted November 10, 2017; accepted January 2, 2018

\begin{abstract}
Keywords: Phosphate glass fibres, Iron, Boron, Mechanical properties, Dissolution behaviour
The previous research has reported the phosphate based glass has potential medical application due to excellent cytocompatibility and controllable degradability. In this study, Six novel phosphate based glass formulations were produced as two glass system $48 \mathrm{P}_{2} \mathrm{O}_{5}-12 \mathrm{~B}_{2} \mathrm{O}_{3}-(25-\mathrm{X}) \mathrm{MgO}-14 \mathrm{CaO}-1 \mathrm{Na}_{2} \mathrm{O}-(\mathrm{X}) \mathrm{Fe}_{2} \mathrm{O}_{3}(\mathrm{X}=6, \quad 8,10)$ and $45 \mathrm{P}_{2} \mathrm{O}_{5}-\left(\mathrm{Y}_{2} \mathrm{~B}_{2} \mathrm{O}_{3}-(32-\mathrm{Y})\right.$ $\mathrm{MgO}-14 \mathrm{CaO}-1 \mathrm{Na}_{2} \mathrm{O}-8 \mathrm{Fe}_{2} \mathrm{O}_{3}(\mathrm{Y}=12,15,20)$ for glass fibre drawing study, whilst five of them were converted to be fibre successfully. The PBG with 20 mol. $\% \mathrm{~B}_{2} \mathrm{O}_{3}$ was difficult to form fibre with stable meniscus due to high viscosity. The mechanical properties of the fibres were found to increase with increasing $\mathrm{B}_{2} \mathrm{O}_{3}$ or $\mathrm{Fe}_{2} \mathrm{O}_{3}$ content in the glass. The highest tensile strength $(1253 \pm 92 \mathrm{MPa})$ was recorded for $48 \mathrm{P}_{2} \mathrm{O}_{5}-12 \mathrm{~B}_{2} \mathrm{O}_{3}-15 \mathrm{MgO}-14 \mathrm{CaO}-1 \mathrm{Na}_{2} \mathrm{O}-10 \mathrm{Fe}_{2} \mathrm{O}_{3}$ glass fibres. The assessment of change in mechanical properties of glass fibres was performed in phosphate buffer saline (PBS) at $37^{\circ} \mathrm{C}$ for 28 days. The mass loss and dissolution rate of glass fibre was reduced with an increase of $\mathrm{Fe}_{2} \mathrm{O}_{3}$ content from 6 to $10 \mathrm{~mol} . \%$ whilst an increase of dissolution rate was observed with increasing $\mathrm{B}_{2} \mathrm{O}_{3}$ content. During the degradation period, a huge decrease on tensile strength was observed, and $20 \sim 40 \%$ tensile strength was residual by 28 -day. Whereas, no significant change $(P>0.05)$ in the tensile modulus was revealed.
\end{abstract}

\section{INTRODUCTION}

Biomaterials are an integral and vital part of the modern orthopaedic bone plate market $[1,2]$. The mechanical strength of glass fibres are known to be different from those of the bulk glass with the same chemical composition [3]. The use of high tensile strength glass fibres has provided fibre-reinforced polymers as a group of new load bearing materials with high mechanical properties and moderate chemical durability for applications such as bone fracture-fixation devices [47]. The demand for biomaterials based on bioactive glass fibre reinforced composites has increased in the past decade [810]. However, the long-term reaction to silica in vivo systematically is still unknown [11].

Phosphate-based glass fibres (PGF) have been evaluated as alternative materials to bioactive silicate glass fibres for reinforcing resorbable polymers in tissue engineering application, since they are fully resorbable and contain large amounts of calcium and phosphorus to support bone mineralisation $[12,14]$. Phosphate glass fibres (PGF) are fabricated conventionally via a melt-drawn system where fibres are drawn from a high temperature glass liquid and collected on a rotating drum [15]. Ahmed et al. [3] developed a range of PBGs in the system $\mathrm{P}_{2} \mathrm{O}_{5}-\mathrm{CaO}-\mathrm{Na}_{2} \mathrm{O}$ with $\mathrm{P}_{2} \mathrm{O}_{5}$ content fixed to 45 ,
50 and $55 \mathrm{~mol} . \%$ and were able to draw fibre from glass with fixed 50 and 55 mol. $\% \mathrm{P}_{2} \mathrm{O}_{5}$, but not with $45 \mathrm{~mol} . \%$ $\mathrm{P}_{2} \mathrm{O}_{5}$. They concluded that the chain length in the glasses played a key role in the fibre-drawing process and the glass with $\mathrm{Q}^{2}$ metaphosphate structure units of infinite chain length were easier to draw into fibre than glasses composed of shorter chain length $\mathrm{Q}^{1}$ pyrophosphate units [3].

It is worth noting that both boron and phosphorous are network formers, and a more interconnected glass network with the creation of cross-linked phosphate chains with B-O-P bonds can be expected from the combination of these two glass network formers [16, 19]. Several studies have reported that the addition of $\mathrm{B}_{2} \mathrm{O}_{3}$ into phosphate based glasses (PBG) forms a crosslinked chain structure and results in the enhancement of chemical durability and thermal stability against crystallisation, which is a common issue associated with the drawing of fibres $[20,22]$. Thus, it was hypothesised in this study that addition of $\mathrm{B}_{2} \mathrm{O}_{3}$ should extend the chain structure in the glass and improve glass stability, thereby improving fibre drawing performance.

Due to the poor thermal stability of phosphate based glasses, phosphate glass fibres are normally produced only in single filament form and in lab-scale quantities (grams) [23]. Single filament limits the use of these fibres 
as they can only be produced as non-woven random or unidirectional fibre mats $[24,25]$. To overcome this issue and extend application area of PGFs, scale-up manu-facture to multi-filament continuous phosphate glass fibre fabrication needs to be achieved and Zhu et al $[26,27]$ have developed a phosphate glass fibre system $\mathrm{P}_{2} \mathrm{O}_{5}-\mathrm{B}_{2} \mathrm{O}_{3}-\mathrm{CaO}-\mathrm{MgO}-\mathrm{Na}_{2} \mathrm{O}-\mathrm{Fe}_{2} \mathrm{O}_{3}$ with excellent thermal stability and fibre drawing performance. However, the poor chemical durability of multifilament PGFs in the composite resulted in catastrophic retention of composite mechanical properties during degradation study [27].

In the literature, it was reported that addition of $\mathrm{B}_{2} \mathrm{O}_{3}$ into phosphate based glass could improve chemical durability and mechanical stability of phosphate based glass [28, 18, 21, 22]. Sharmin et al. [29] developed several borophosphate based glass composition and reported that the glass transition temperature was increased whilst the dissolution rate was reduced significantly with addition of $\mathrm{B}_{2} \mathrm{O}_{3}$ into the glass network. It was confirmed also reported by Lim et al., [30] who explained the formation of covalent $\mathrm{B}-\mathrm{O}-\mathrm{P}$ bonding producing a stronger, better chemically resistant glass network with higher packing density and lower crystallisation tendency. Additionally, researchers also showed that the addition of $\mathrm{MgO}$ into phosphate based glass could connect chain structure of phosphate based glass and transfer open metaphosphate glass structure to more compact structure, thus improve the glass structure stability [14]. Moreover, $\mathrm{Fe}_{2} \mathrm{O}_{3}$ dropped into the glass network could show a much more durable degrada-tion behaviour and favourable cytocompatibility [31]. However, till to date, the effect on thermal properties, degradation behaviour and glass structure of phosphate based glass by substitution of $\mathrm{MgO}$ with $\mathrm{B}_{2} \mathrm{O}_{3}$, and replacing $\mathrm{MgO}$ with $\mathrm{Fe}_{2} \mathrm{O}_{3}$ have not been investigated significantly.

In this study, a range of novel complex PBGs in the system of $48 \mathrm{P}_{2} \mathrm{O}_{5}-12 \mathrm{~B}_{2} \mathrm{O}_{3}-(25-\mathrm{X}) \mathrm{MgO}-14 \mathrm{CaO}$ $-1 \mathrm{Na}_{2} \mathrm{O}-(\mathrm{X}) \mathrm{Fe}_{2} \mathrm{O}_{3}$, where $\mathrm{X}=6,8,10$; and $45 \mathrm{P}_{2} \mathrm{O}_{5}-(\mathrm{Y})$ $\mathrm{B}_{2} \mathrm{O}_{3}-(32-\mathrm{Y}) \mathrm{MgO}-14 \mathrm{CaO}-1 \mathrm{Na}_{2} \mathrm{O}-8 \mathrm{Fe}_{2} \mathrm{O}_{3}$, where $\mathrm{Y}=12$, 15,20 were considered based on the formula $48 \mathrm{P}_{2} \mathrm{O}_{5}$ $12 \mathrm{~B}_{2} \mathrm{O}_{3}-14 \mathrm{CaO}-20 \mathrm{MgO}-1 \mathrm{Na}_{2} \mathrm{O}-5 \mathrm{Fe}_{2} \mathrm{O}_{3}$ [26], and an investigation into their structural, degradation properties and fibre drawing performance have been conducted. The mechanical properties of glass fibre during degradation were conducted in phosphate buffer saline (PBS) solution.

\section{EXPERIMENTAL}

\section{Glass preparation}

The glasses in this study were manufacture in Sinoma Co.,Ltd (China) using phosphorous pentoxide $\left(\mathrm{P}_{2} \mathrm{O}_{5}\right)$, boric acid $\left(\mathrm{H}_{3} \mathrm{BO}_{3}\right)$, calcium hydrogen phosphate dehydrate $\left(\mathrm{CaHPO}_{4} \cdot 2 \mathrm{H}_{2} \mathrm{O}\right)$, magnesium hydrogen phosphate trihydrate $\left(\mathrm{MgHPO}_{4} \cdot 3 \mathrm{H}_{2} \mathrm{O}\right)$, sodium dihydrogen phosphate dehydrate $\left(\mathrm{NaH}_{2} \mathrm{PO}_{4} \cdot 2 \mathrm{H}_{2} \mathrm{O}\right)$, potassium dihydrogen phosphate $\left(\mathrm{KH}_{2} \mathrm{PO}_{4}\right)$, and iron(III)-phosphate Tetrahydrate $\left(\mathrm{FePO}_{4} \cdot 4 \mathrm{H}_{2} \mathrm{O}\right)$ (Sinopharm Group, China). The precursors were weighted out and placed into a large Pt crucible which was built in the customised furnace composed of $\mathrm{Al}_{2} \mathrm{O}_{3}$. When all the mixed precursors had been added, they were heated using a silicon carbide rod by direct resistance heating. After 24 hours heating at $1200^{\circ} \mathrm{C}$, the melted glass was poured into a stainless steel bucket water for cooling and collecting. The cooled glasses were then removed from the bucket and dried in oven for 12 hours. $5 \mathrm{~kg}$ glass batches were manufactured for each composition.

\section{Differential scanning calorimetry} (DSC)

Bulk glasses of the different compositions were ground to fine powder using a pestle and mortar. The glass transition temperature $T_{g}$, crystallisation temperature $\mathrm{T}_{c}$, melting point $T_{m}$ and liquidus temperature $\mathrm{T}_{1}$ of the glasses was determined using a differential scanning calorimetry (DSC, TA Instruments SDT Q600, UK). Samples of approximately $30 \mathrm{mg}$ of the glass powders were heated from room temperature to $1200^{\circ} \mathrm{C}$ at $10^{\circ} \mathrm{C} \cdot \mathrm{min}^{-1}$ in flowing nitrogen gas. A blank run was carried out to determine the baseline which was then subtracted from the traces obtained. The $T_{g}$ was extrapolated from the midpoint in the endothermic reaction of the heat flow. The first deviation of the DSC curve from the base line above $T_{g}$ and the melting point and liquidus temperature were taken as the $T_{m}$ and $T_{L}$, respectively.

\section{Single filament fibre preparing}

Continuous single filament phosphate glass fibre was produced via a conventional glass fibre melt-drawing spinning process. The glasses were added into a Ptcrucible with a single tipped bushing, which was heated by electrical power, held isothermally for 1 hour at $1150^{\circ} \mathrm{C}$ in order to melt the glass completely. Subsequently, fibre was drawn manually from the bushing tip and an air cooling system was utilised to cool the glass meniscus rapidly in order to increase the viscosity of the glass to fibre forming viscosity $\left(\log _{10} 2 \mathrm{~Pa} \cdot \mathrm{s}\right)$. Continuous single filament fibre was collected onto a winder at a constant drawing speed.

\section{Density analysis of PGF}

The density of the fibres was determined following BS 10119 [32] based on Archimedes' principle. A bundle of fibres $(5 \mathrm{~g})$ was formed into knot shape and placed on the specimen support of analytical balance for weighing in air. Then, the specimen support was immersed in the beaker filled with ethanol (Sinopharm Group, China) and the knotted fibres were placed on the specimen 
support for weighing again with immersion in ethanol completely. The final density of fibres $\left(\rho_{f}\right)$ could be calculated by Equation 1 .

$$
\rho_{f}=\left(\frac{\mathrm{M}_{a}}{\mathrm{M}_{a}-\mathrm{M}_{w}}\right) \rho_{e}
$$

where, $M_{a}$ is the mass of fibre weighed in air, $M_{w}$ is the mass of fibre immersed in ethanol and $\rho_{e}$ is the density of ethanol.

\section{Degradation study of fibres}

A dissolution study was conducted on fibre produced. Based on BS 10993-13 [33], the fibres of each group were chopped into an average length of $50 \mathrm{~mm}$ and approximately $300 \mathrm{mg}$ fibres were placed into the middle of individual glass vials each containing $30 \mathrm{ml}$ of phosphate buffer saline (PBS) solution. The time points used were $0,1,3,7,11,15,21$ and 28 days.

At each time point, the $\mathrm{pH}$ of the solution was measured using a bench-top $\mathrm{pH}$ meter (Mettler Toledo, USA) which was calibrated using standard $\mathrm{pH}$ buffer solutions at $\mathrm{pH} 4.0$ and $\mathrm{pH} 7.0$ (Fisher Scientific, UK) prior to each measurement. The PBS solution in vials was withdrawn carefully by using a syringe with a needle of $0.8 \mathrm{~mm}$ diameter (BD Microlance, Germany), in case chopped fibres were sucked along with PBS flow. Deionised water was used to refill the vials and removed in same method after gently shaking vials in order to wash all residual chemical substance of PBS from the fibres. The fibres after washing were placed into a drying oven at $50^{\circ} \mathrm{C}$ for 24 hours. The PBS solution in the remaining, later time point, vials was replaced at each time point.

\section{Single fibre tensile test}

Single fibre tensile tests were carried out based on BS 11566 [34]. For each time point, twenty dried fibres for each fibre group were mounted individually on plastic tabs, with a $20 \mathrm{~mm}$ gauge length testing setup. The ends of each fibre were bonded to the plastic tab with an acrylic adhesive (Dymax 3099, Germany) which was cured using UV light. The diameter of each fibre was measured by using a laser scan micrometer (LSM 6200, Mitutoya, Japan) which was calibrated with glass fibre of known diameter (determined by SEM). The tensile strength of fibre was determined by using a LEX820 tensile tester (UK) at room temperature with a load capacity of $2 \mathrm{~N}$ and a speed of $0.017 \mathrm{~mm} \cdot \mathrm{s}^{-1}$. A one-way ANOVA statistical analysis was used to study the effect of fibre surface coatings and heat treatment on the mechanical properties of fibre, and the retention of mechanical properties during fibre degradation.

The Weibull distribution is a well-known method to describe the strength of fibres [35]. Weibull modulus and normalising stress are presented as the shape and scale value. The normalising stress $\sigma_{0}$ is regarded as the most probable stress at which a fibre of length $\mathrm{L}_{0}$ will fail [36]. The most probable failure strength can be taken as the stress at which $63.2 \%$ of tested fibre has failed [37]. In this study, the Weibull parameters were obtained from the tensile fracture stress data by using Minitab (version 17.2.1).

\section{SEM analysis}

Scanning electron microscopy was taken to observe variations in the surface morphology of fibres after degradation. The fibres were sputter coated with platinum and examined with a Philips XL30 Scanning electron microscope operated at $10 \mathrm{kV}$.

\section{Statistical analysis}

The average values and standard error of all data involved in study of this chapter were calculated and analysed using the Prism software (version 6.0, GraphpPad Software, San Diego, CA, USA). A one-way analysis of variance (ANOVA) was calculated with the Tukey multiple post-test to compare the significance of change in one factor with time. The error bars on all the data represents standard error of mean with $n=20$.

\section{RESULTS}

\section{Single filament fibre drawing}

Thermal analysis of phosphate glass system $48 \mathrm{P}_{2} \mathrm{O}_{5}-$ $-12 \mathrm{~B}_{2} \mathrm{O}_{3}-(25-\mathrm{X}) \mathrm{MgO}-14 \mathrm{CaO}-1 \mathrm{Na}_{2} \mathrm{O}-(\mathrm{X}) \mathrm{Fe}_{2} \mathrm{O}_{3}$, and $45 \mathrm{P}_{2} \mathrm{O}_{5}-(\mathrm{Y}) \mathrm{B}_{2} \mathrm{O}_{3}-(32-\mathrm{Y}) \mathrm{MgO}-14 \mathrm{CaO}-1 \mathrm{Na}_{2} \mathrm{O}-8 \mathrm{Fe}_{2} \mathrm{O}_{3}$ shows the melting point $\left(T_{m}\right)$ and liquidus temperature $\left(T_{L}\right)$ of glass in the Table 1 , as important reference for glass fibre drawing. During the glass fibre drawing, temperature of furnace $\left(T_{f}\right)$ was around $1150^{\circ} \mathrm{C}$ in order to fully melt phosphate based glass before moving into the bushing area, whilst temperature of bushing $\left(T_{b}\right)$ was around $30^{\circ} \mathrm{C}$ above liquidus temperature $\left(T_{L}\right)$ in order to make sure the stable meniscus of fibre during the glass forming. In this study, there are five glass formulation were able to form fibre successfully with diameter between $9 \sim 13 \mu \mathrm{m}$ (See Table 1).

The density analysis of glass fibre presented the value of density increased from 2.84 to $3.02 \times 10^{3} \mathrm{~kg} \cdot \mathrm{m}^{-3}$ with increase of $\mathrm{Fe}_{2} \mathrm{O}_{3}$ content for MgP-Fe glass system, whilst the increase in the density was observed for $\mathrm{MgP}-\mathrm{B}$ glass system from 2.92 to $3.02 \times 10^{3}$ when $\mathrm{B}_{2} \mathrm{O}_{3}$ content increased from $12 \mathrm{~mol} \%$ to $15 \mathrm{~mol} \%$.

\section{Initial tensile properties of fibres}

Figure 2 shows the effect of increasing $\mathrm{Fe}_{2} \mathrm{O}_{3}$ and $\mathrm{B}_{2} \mathrm{O}_{3}$ on the mechanical properties (tensile strength and modulus) of the fibres. An increase in tensile strength was seen with an increase in $\mathrm{Fe}_{2} \mathrm{O}_{3}$ content. The tensile 
strength of MgP-Fe6 was $1021 \pm 62 \mathrm{MPa}$, increased to $1179 \pm 63 \mathrm{MPa}$ for MgP-Fe8 and $1253 \pm 92 \mathrm{MPa}$ for $\mathrm{MgP}-\mathrm{Fe} 10$. Additionally, the tensile strength of MgP-B12 and MgP-B15 was $1055 \pm 91 \mathrm{MPa}$ and $1105 \pm 65 \mathrm{MPa}$ respectively, whilst MgP-B20 was not reported as it was not possible to pull the fibres due to the high viscosity

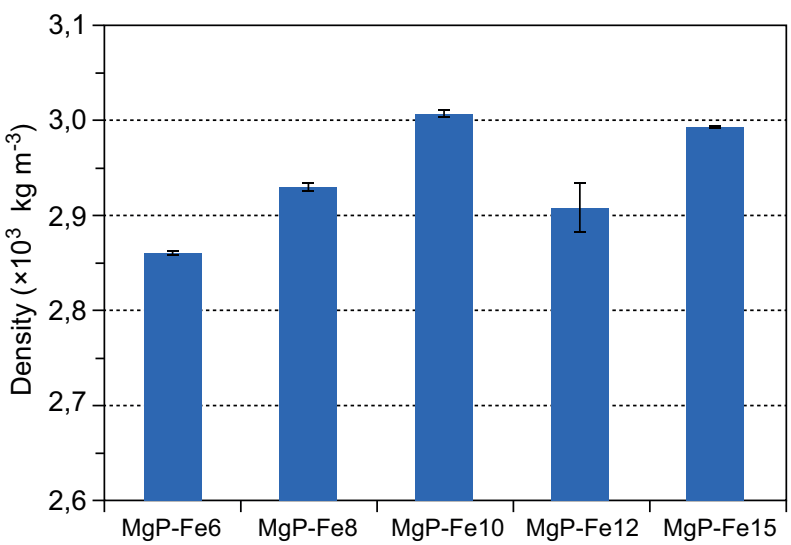

Figure 1. Density of the glass fibre in the system $48 \mathrm{P}_{2} \mathrm{O}_{5}$ $-12 \mathrm{~B}_{2} \mathrm{O}_{3}-(25-\mathrm{X}) \mathrm{MgO}-14 \mathrm{CaO}-1 \mathrm{Na}_{2} \mathrm{O}-(\mathrm{X}) \mathrm{Fe}_{2} \mathrm{O}_{3}$, where $\mathrm{X}=$ $=6,8,10$; and $45 \mathrm{P}_{2} \mathrm{O}_{5}-(\mathrm{Y}) \mathrm{B}_{2} \mathrm{O}_{3}-(32-\mathrm{Y}) \mathrm{MgO}-14 \mathrm{CaO}-1 \mathrm{Na}_{2} \mathrm{O}-$ $-8 \mathrm{Fe}_{2} \mathrm{O}_{3}$, where $\mathrm{Y}=12,15$ (error bars represent the standard deviation where $\mathrm{n}=20$ ).

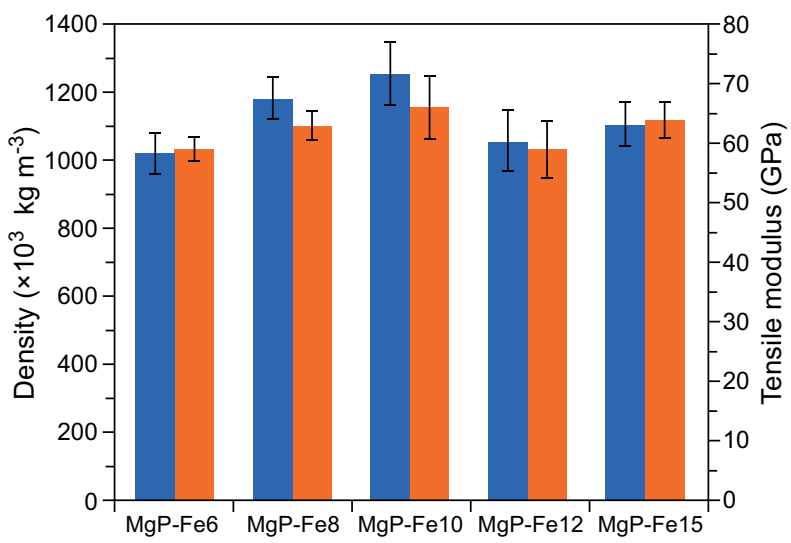

Figure 2. Tensile strength and tensile modulus of glass fibre in the system $48 \mathrm{P}_{2} \mathrm{O}_{5}-12 \mathrm{~B}_{2} \mathrm{O}_{3}-(25-\mathrm{X}) \mathrm{MgO}-14 \mathrm{CaO}-1 \mathrm{Na}_{2} \mathrm{O}-(\mathrm{X})$ $\mathrm{Fe}_{2} \mathrm{O}_{3}$, where $\mathrm{X}=6,8,10$; and $45 \mathrm{P}_{2} \mathrm{O}_{5}-(\mathrm{Y}) \mathrm{B}_{2} \mathrm{O}_{3}-(32-\mathrm{Y}) \mathrm{MgO}-$ $-14 \mathrm{CaO}-1 \mathrm{Na}_{2} \mathrm{O}-8 \mathrm{Fe}_{2} \mathrm{O}_{3}$, where $\mathrm{Y}=12,15$ (error bars represent the standard deviation where $\mathrm{n}=20$ ). and unstable meniscus of fibre during the fibre drawing. The highest tensile fibre strength $(1253 \pm 92 \mathrm{MPa})$ was observed for $\mathrm{MgP}-\mathrm{Fe} 10$ fibres, and an increase in tensile strength from $1021 \pm 62$ to $1253 \pm 92 \mathrm{MPa}$ for $\mathrm{MgP}-\mathrm{Fe}$ glass system was observed with increasing $\mathrm{Fe}_{2} \mathrm{O}_{3}$ from 6 to $10 \mathrm{~mol}$. \%. Furthermore, an increase of tensile strength for $\mathrm{MgP}-\mathrm{B}$ glass system with increasing $\mathrm{B}_{2} \mathrm{O}_{3}$ from 12 to $15 \mathrm{~mol}$. \% was also observed. The trend of normalising strength $\sigma_{0}$ in Table 2 was consistent with the trend of average tensile strength. The Weibull modulus of these fibres was seen to range from 8.1 - 10.6.

The trend of modulus for glasses fibres presented consistent variation with that of tensile strength. An increase in modulus from $59 \pm 2 \mathrm{GPa}$ to $66 \pm 5 \mathrm{GPa}$ was observed for MgP-Fe glass fibre with increasing $\mathrm{Fe}_{2} \mathrm{O}_{3}$ content from 6 to $10 \mathrm{~mol}$. \%. The increase of modulus for $\mathrm{MgP}-\mathrm{B}$ glass fibre system was also revealed an increase of tensile modulus from $59 \pm 5 \mathrm{GPa}$ to $64 \pm 3 \mathrm{GPa}$ with addition of $\mathrm{B}_{2} \mathrm{O}_{3}$ from 12 to $15 \mathrm{~mol}$. \%.

Table 2. Weibull distribution of glass fibre in the system $48 \mathrm{P}_{2} \mathrm{O}_{5}-12 \mathrm{~B}_{2} \mathrm{O}_{3}-(25-\mathrm{X}) \mathrm{MgO}-14 \mathrm{CaO}-1 \mathrm{Na}_{2} \mathrm{O}-(\mathrm{X}) \mathrm{Fe}_{2} \mathrm{O}_{3}$, where $\mathrm{X}=6,8,10$; and $45 \mathrm{P}_{2} \mathrm{O}_{5}-\left(\mathrm{Y}^{2} \mathrm{~B}_{2} \mathrm{O}_{3}-(32-\mathrm{Y}) \mathrm{MgO}-\right.$ $14 \mathrm{CaO}-1 \mathrm{Na}_{2} \mathrm{O}-8 \mathrm{Fe}_{2} \mathrm{O}_{3}$, where $\mathrm{Y}=12,15,20$.

\begin{tabular}{lccc}
\hline Fibre code & $\begin{array}{c}\text { Tensile } \\
\text { strength } \\
(\mathrm{MPa})\end{array}$ & $\begin{array}{c}\text { Normalising } \\
\text { strength } \sigma_{0} \\
(\mathrm{MPa})\end{array}$ & $\begin{array}{c}\text { Weibull } \\
\text { modulus } \\
(\mathrm{m})\end{array}$ \\
\hline MgP-Fe6 & $1021 \pm 61$ & 1172 & 10.2 \\
MgP-Fe8 & $1180 \pm 62$ & 1242 & 10.1 \\
MgP-Fe10 & $1253 \pm 92$ & 1305 & 8.1 \\
MgP-B12 & $1055 \pm 91$ & 1105 & 8.9 \\
MgP-B15 & $1105 \pm 65$ & 1189 & 10.6 \\
\hline
\end{tabular}

\section{Dissolution behaviour of the degraded fibres}

Figure 3 represented the mass loss of $\mathrm{MgP}-\mathrm{Fe}$ and $\mathrm{MgP}-\mathrm{B}$ glass fibres during 28 days of dissolution in the PBS at $37^{\circ}$, whilst the estimated dissolution rate of the fibres was shown in Figure 4. It was evident that the mass loss of the glass fibres was increased with fibre immersion in the PBS during the degradation period. For $\mathrm{MgP}-\mathrm{Fe}$ glass fibres the dissolution rate was increased

Table 1. The melting point $\left(\mathrm{T}_{m}\right)$, liquidus temperature $\left(\mathrm{T}_{\mathrm{L}}\right)$, temperature of furnace $\left(\mathrm{T}_{f}\right)$, temperature of bushing $\left(\mathrm{T}_{\mathrm{b}}\right)$ of glasses, fibre drawing statues and diameter of glass fibre in the system $48 \mathrm{P}_{2} \mathrm{O}_{5}-12 \mathrm{~B}_{2} \mathrm{O}_{3}-(25-\mathrm{X}) \mathrm{MgO}-14 \mathrm{CaO}-1 \mathrm{Na}_{2} \mathrm{O}-(\mathrm{X}) \mathrm{Fe} \mathrm{O}_{2}$, where $\mathrm{X}=6,8,10$; and $45 \mathrm{P}_{2} \mathrm{O}_{5}-(\mathrm{Y}) \mathrm{B}_{2} \mathrm{O}_{3}-(32-\mathrm{Y}) \mathrm{MgO}-14 \mathrm{CaO}-1 \mathrm{Na}_{2} \mathrm{O}-8 \mathrm{Fe}_{2} \mathrm{O}_{3}$, where $\mathrm{Y}=12,15,20$.

\begin{tabular}{|c|c|c|c|c|c|c|}
\hline Glass code & $\mathrm{T}_{\mathrm{m}}\left({ }^{\circ} \mathrm{C}\right)$ & $\mathrm{T}_{\mathrm{L}}\left({ }^{\circ} \mathrm{C}\right)$ & $\mathrm{T}_{\mathrm{f}}\left({ }^{\circ} \mathrm{C}\right)$ & $\mathrm{T}_{\mathrm{b}}\left({ }^{\circ} \mathrm{C}\right)$ & Fibre drawing & Diameter $(\mu \mathrm{m})$ \\
\hline MgP-Fe6 & $906 \pm 2$ & $922 \pm 2$ & $1155 \pm 7$ & $950 \pm 5$ & Success & $9 \sim 13$ \\
\hline MgP-Fe8 & $886 \pm 5$ & $935 \pm 5$ & $1152 \pm 4$ & $950 \pm 4$ & Success & $9 \sim 13$ \\
\hline MgP-Fe10 & $841 \pm 7$ & $956 \pm 7$ & $1149 \pm 5$ & $980 \pm 4$ & Success & $9 \sim 13$ \\
\hline MgP-B12 & $938 \pm 8$ & $968 \pm 8$ & $1153 \pm 3$ & $985 \pm 6$ & Success & $9 \sim 13$ \\
\hline MgP-B15 & $903 \pm 5$ & $936 \pm 6$ & $1155 \pm 3$ & $955 \pm 3$ & Success & $9 \sim 13$ \\
\hline MgP-B20 & $932 \pm 7$ & $958 \pm 13$ & $1152 \pm 5$ & $980 \pm 2$ & Failure & N/A \\
\hline
\end{tabular}


with addition of $\mathrm{Fe}_{2} \mathrm{O}_{3}$ from 6 to $10 \mathrm{~mol}$. \%, as well as the mass loss of MgP-B glass fibres which was increased with addition of $\mathrm{B}_{2} \mathrm{O}_{3}$ from 12 to 15 mol. \%. After 28 days of degradation, the dissolution rate of $\mathrm{MgP}-\mathrm{Fe} 6, \mathrm{MgP}-$ Fe8 and MgP-Fe10 fibres was $1.01 \times 10^{-8}, 6.92 \times 10^{-9}$, $5.76 \times 10^{-9} \mathrm{~kg} \cdot \mathrm{m}^{-2} \cdot \mathrm{s}^{-1}$, respectively. Additionally, the dissolution rate of $5.24 \times 10^{-9}$ and $6.67 \times 10^{-9} \mathrm{~kg} \cdot \mathrm{m}^{-2} \cdot \mathrm{s}^{-1}$ was observed for MgP-B12 and MgP-B15 fibres.

\section{Mechanical properties of degraded fibres}

The change in tensile strength and modulus of the fibres with degradation is shown in Figure 5 and 6 . These fibres with addition of $\mathrm{B}_{2} \mathrm{O}_{3}$ and $\mathrm{Fe}_{2} \mathrm{O}_{5}$ could be tested up to 28 day interval of immersion even though they were brittle and hard to handle. During the initial 15 days immersion, the tensile strength of glass fibres ( $\mathrm{MgP}-\mathrm{Fe}$ and $\mathrm{MgP}-\mathrm{B}$ ) was seen to decrease rapidly, to almost half of their initial values. After 15-day immersion, the

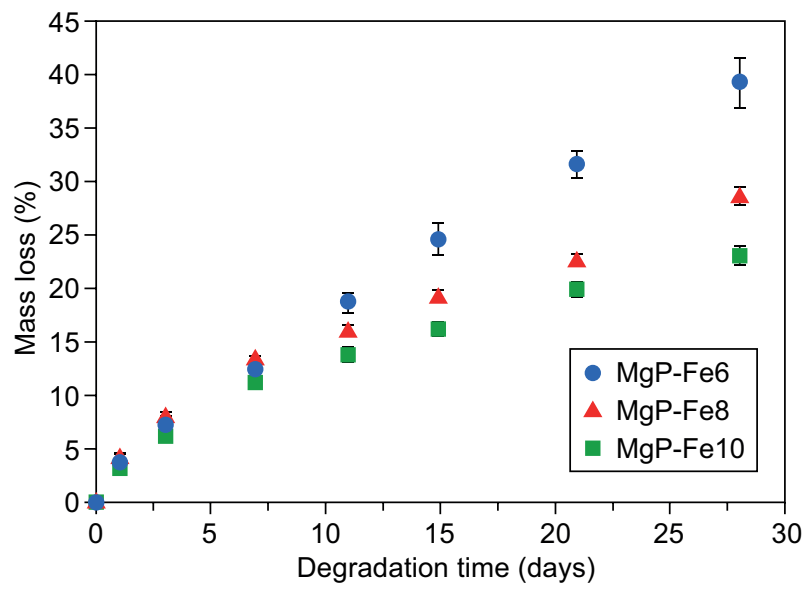

a)

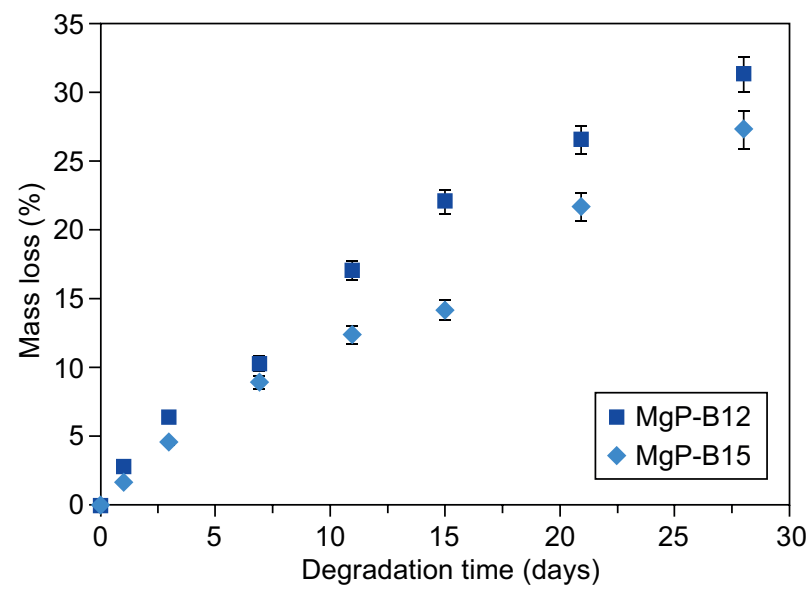

b)

Figure 3. The mass loss of glass fibre in the system: a) $48 \mathrm{P}_{2} \mathrm{O}_{5}-$ $12 \mathrm{~B}_{2} \mathrm{O}_{3}-(25-\mathrm{X}) \mathrm{MgO}-14 \mathrm{CaO}-1 \mathrm{Na}_{2} \mathrm{O}-(\mathrm{X}) \mathrm{Fe}_{2} \mathrm{O}_{3}$, where $\mathrm{X}=$ $6,8,10$; b) $45 \mathrm{P}_{2} \mathrm{O}_{5}-(\mathrm{Y}) \mathrm{B}_{2} \mathrm{O}_{3}-(32-\mathrm{Y}) \mathrm{MgO}-14 \mathrm{CaO}-1 \mathrm{Na}_{2} \mathrm{O}-$ $8 \mathrm{Fe}_{2} \mathrm{O}_{3}$, where $\mathrm{Y}=12,15$, during degradation period. Error bar represent the standard deviation $(n=20)$.

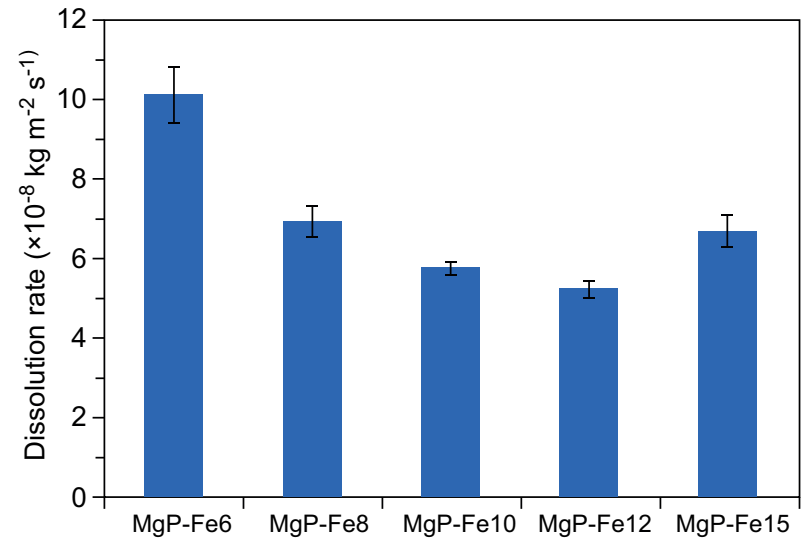

Figure 4. The dissolution rate of glass fibre in the system: a) $48 \mathrm{P}_{2} \mathrm{O}_{5}-12 \mathrm{~B}_{2} \mathrm{O}_{3}-(25-\mathrm{X}) \mathrm{MgO}-14 \mathrm{CaO}-1 \mathrm{Na}_{2} \mathrm{O}-(\mathrm{X}) \mathrm{Fe}_{2} \mathrm{O}_{3}$, where $\mathrm{X}=6,8,10$; b) $45 \mathrm{P}_{2} \mathrm{O}_{5}-(\mathrm{Y}) \mathrm{B}_{2} \mathrm{O}_{3}-(32-\mathrm{Y}) \mathrm{MgO}-14 \mathrm{CaO}-1 \mathrm{Na}_{2} \mathrm{O}-$ $-8 \mathrm{Fe}_{2} \mathrm{O}_{3}$, where $\mathrm{Y}=12,15$, during degradation period. Error bar represent the standard deviation $(\mathrm{n}=20)$.

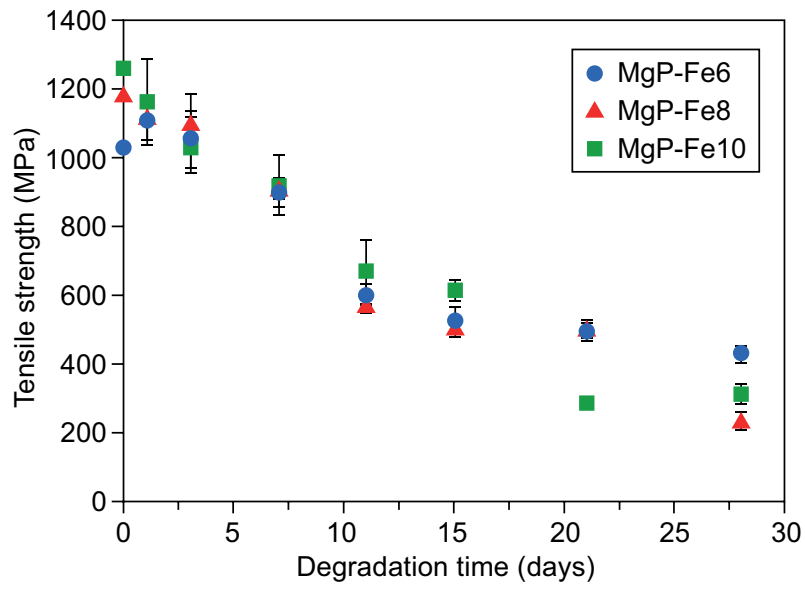

a)

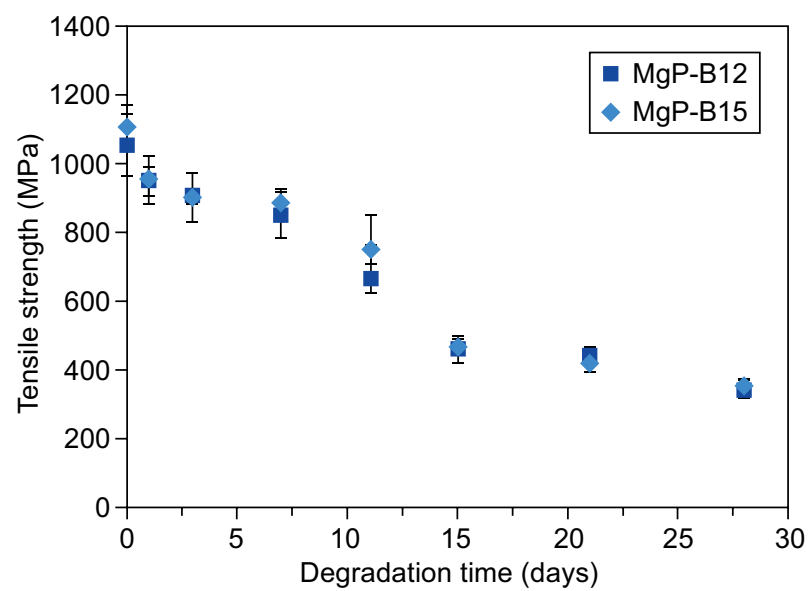

b)

Figure 5. The change in tensile strength of glass fibre in the system: a) $48 \mathrm{P}_{2} \mathrm{O}_{5}-12 \mathrm{~B}_{2} \mathrm{O}_{3}-(25-\mathrm{X}) \mathrm{MgO}-14 \mathrm{CaO}-1 \mathrm{Na}_{2} \mathrm{O}-(\mathrm{X})$ $\mathrm{Fe}_{2} \mathrm{O}_{3}$, where $\mathrm{X}=6,8,10$; b) $45 \mathrm{P}_{2} \mathrm{O}_{5}-\left(\mathrm{Y}^{2} \mathrm{~B}_{2} \mathrm{O}_{3}-(32-\mathrm{Y}) \mathrm{MgO}-\right.$ $-14 \mathrm{CaO}-1 \mathrm{Na}_{2} \mathrm{O}-8 \mathrm{Fe}_{2} \mathrm{O}_{3}$, where $\mathrm{Y}=12,15$, during degradation period. Error bar represent the standard deviation $(n=20)$. 
tensile strength for $\mathrm{MgP}-\mathrm{Fe} 6, \mathrm{MgP}-\mathrm{Fe} 8$ and $\mathrm{MgP}-\mathrm{Fe} 10$ has decreased from $1021 \pm 62 \mathrm{MPa}, 1179 \pm 63 \mathrm{MPa}$ and $1253 \pm 92 \mathrm{MPa}$ to $521 \pm 43 \mathrm{MPa}, 507 \pm 13 \mathrm{MPa}$ and $609 \pm 27 \mathrm{MPa}$, respectively. With further immersion in PBS up to 28 days, the final tensile strength was reduced to

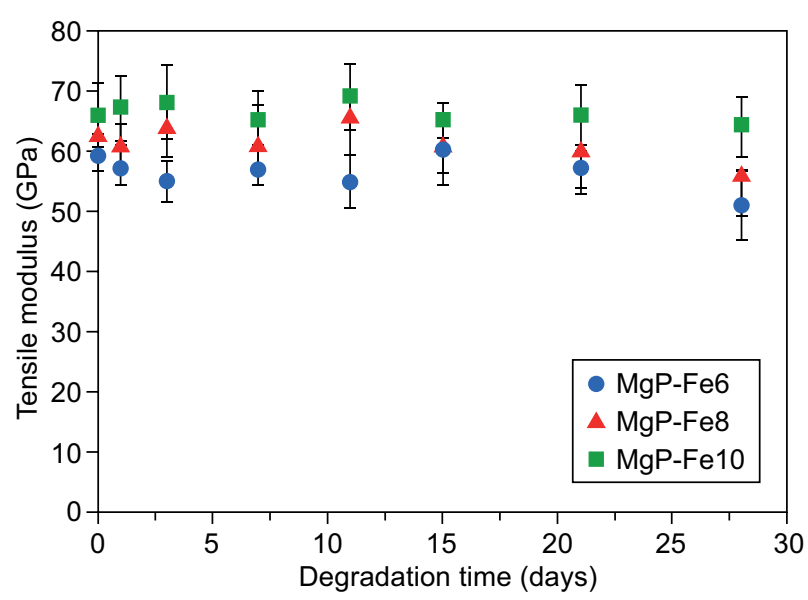

a)
$424 \pm 22 \mathrm{MPa}, 232 \pm 21 \mathrm{MPa}$ and $307 \pm 56 \mathrm{MPa}$, respec-tively. Also, for the glass fibre of $\mathrm{MgP}-\mathrm{B}$, the tensile strength was decreased from $1055 \pm 91 \mathrm{MPa}$ and $1105 \pm 65 \mathrm{MPa}$ to $457 \pm 41 \mathrm{MPa}, 460 \pm 19 \mathrm{MPa}$ by 28 days degradation. On the other hand, for $\mathrm{MgP}-\mathrm{Fe}$

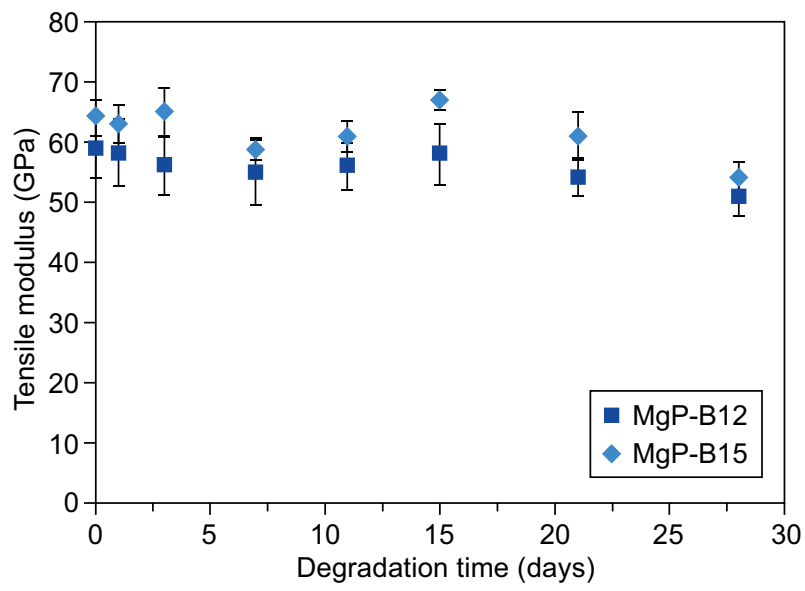

b)

Figure 6. The change in tensile modulus of glass fibre in the system: a) $48 \mathrm{P}_{2} \mathrm{O}_{5}-12 \mathrm{~B}_{2} \mathrm{O}_{3}-(25-\mathrm{X}) \mathrm{MgO}-14 \mathrm{CaO}-1 \mathrm{Na}_{2} \mathrm{O}-(\mathrm{X}) \mathrm{Fe}_{2} \mathrm{O}_{3}$, where $\mathrm{X}=6,8,10$; b) $45 \mathrm{P}_{2} \mathrm{O}_{5}-(\mathrm{Y}) \mathrm{B}_{2} \mathrm{O}_{3}-(32-\mathrm{Y}) \mathrm{MgO}-14 \mathrm{CaO}-1 \mathrm{Na}_{2} \mathrm{O}-8 \mathrm{Fe}_{2} \mathrm{O}_{3}$, where $\mathrm{Y}=12,15$, during degradation period. Error bar represent the standard deviation $(\mathrm{n}=20)$.

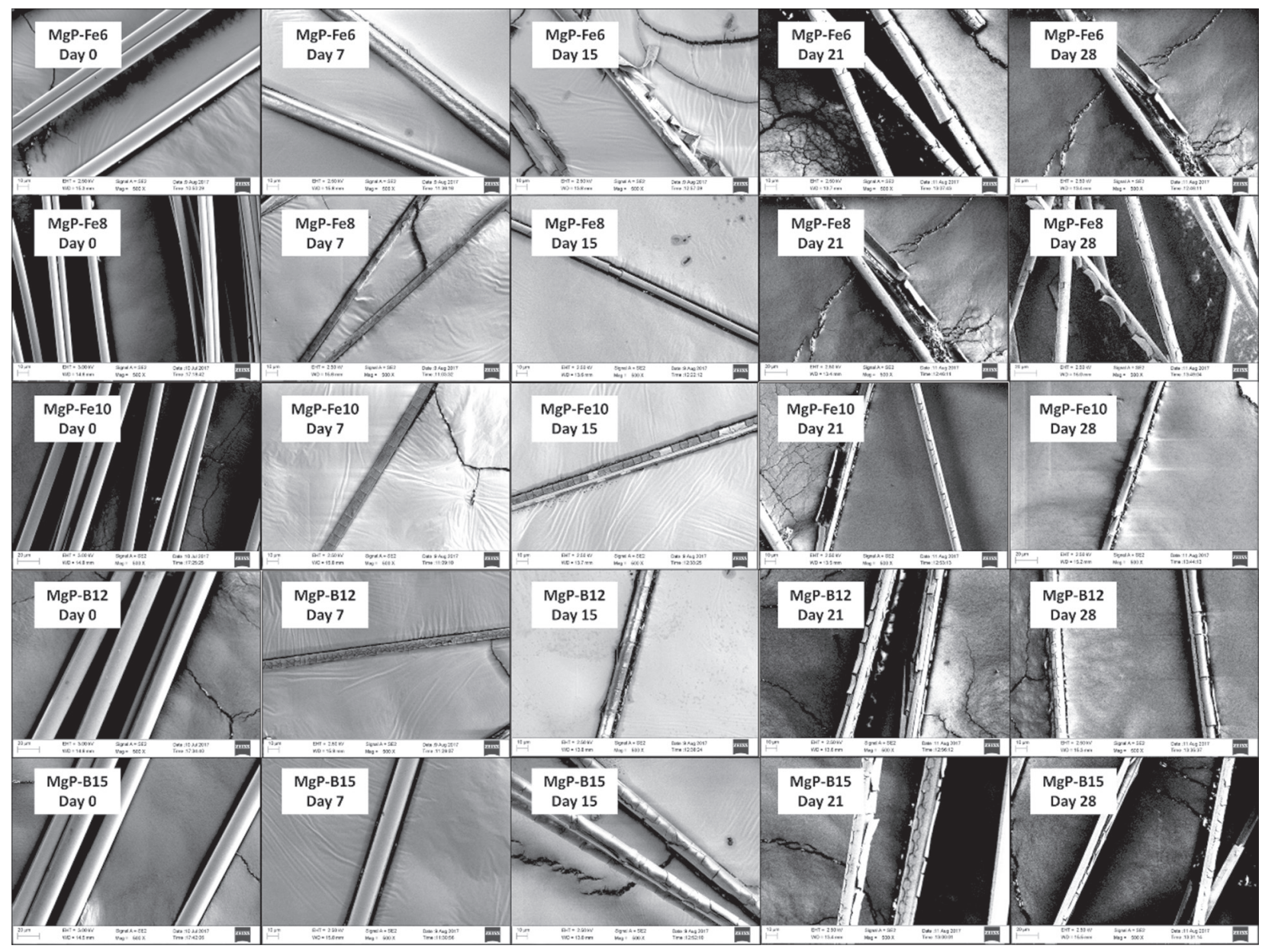

Figure 7. Scanning electron microscopy of glass fibre in the system $48 \mathrm{P}_{2} \mathrm{O}_{5}-12 \mathrm{~B}_{2} \mathrm{O}_{3}-(25-\mathrm{X}) \mathrm{MgO}-14 \mathrm{CaO}-1 \mathrm{Na}_{2} \mathrm{O}-(\mathrm{X}) \mathrm{Fe}_{2} \mathrm{O}_{3}$, where $\mathrm{X}=6,8,10$; b) $45 \mathrm{P}_{2} \mathrm{O}_{5}-(\mathrm{Y}) \mathrm{B}_{2} \mathrm{O}_{3}-(32-\mathrm{Y}) \mathrm{MgO}-14 \mathrm{CaO}-1 \mathrm{Na}_{2} \mathrm{O}-8 \mathrm{Fe}_{2} \mathrm{O}_{3}$, where $\mathrm{Y}=12,15$, at degradation period of day. Error bar represent the standard deviation $(\mathrm{n}=20)$. 
glass fibres, there is no significant difference $(\mathrm{P}>0.05)$ in tensile strength was observed up to day 7 interval. For MgP-B glass fibres, no significant difference $(\mathrm{P}>0.05)$ in tensile strength was observed up to day 11 interval. On the other hand, no statistically variation on the fibre tensile modulus was observed over the degradation period. The SEM image of surface morphologies of fibre in the Figure 7 revealed the peeling effect on the fibre surface was seen from day 15-degraded fibres. A decrease in diameter was also found after peeling off with degradation over time, resulted in the brittle fibre with difficulty for handling.

\section{DISCUSSION}

Phosphate based glass fibres have been investigated as potential biomaterials for biomedical applications as the composition of the glass can be tailored to match the final application such as reinforcements for bone repair implants [38, 23]. The fibre drawing performance of glass fibre was strongly dependent on the structure of the glass, in particular the Q units [39]. Normally, the phosphate based glass with full metaphosphate structure units $\left(\mathrm{Q}^{2}\right)$ were found to be easily converted into fibre form due to the long-chain structure improving fibre drawing performance [15]. Additionally, the degradation behaviour of glasses played important role on the cytocompatibility as ions released from the fibre in vivo demonstrated the side effect on the tissue [40, 41]. Therefore, phosphate glass fibres with great fibre drawing performance and required degradation profiles are highly desired for further application in medical area.

It was hypothesised that increased $\mathrm{Fe}_{2} \mathrm{O}_{3}$ and $\mathrm{B}_{2} \mathrm{O}_{3}$ content in the glass composition could improve the fibre drawing performance and chemical durability of the glass fibre. Addition of $\mathrm{B}_{2} \mathrm{O}_{3}$ into the glass network has been reported to create $\mathrm{B}-\mathrm{O}-\mathrm{P}$ bonds to crosslink phosphate chains and resulted in improvement of thermal stability for fibre drawing [15].

In this study, there were two glass system $48 \mathrm{P}_{2} \mathrm{O}_{5}-12 \mathrm{~B}_{2} \mathrm{O}_{3}-(25-\mathrm{X}) \mathrm{MgO}-14 \mathrm{CaO}-1 \mathrm{Na}_{2} \mathrm{O}-(\mathrm{X})$ $\mathrm{Fe}_{2} \mathrm{O}_{3}$, where $\mathrm{X}=6,8,10(\mathrm{MgP}-\mathrm{Fe})$; and $45 \mathrm{P}_{2} \mathrm{O}_{5}-(\mathrm{Y})$ $\mathrm{B}_{2} \mathrm{O}_{3}-(32-\mathrm{Y}) \mathrm{MgO}-14 \mathrm{CaO}-1 \mathrm{Na}_{2} \mathrm{O}-8 \mathrm{Fe}_{2} \mathrm{O}_{3}$, where $\mathrm{Y}=12$ 15,20 (MgP-B) were studied and produced for fibres. It was found that the phosphate based glass with $\mathrm{Fe}_{2} \mathrm{O}_{3}$ with range from 6 to $10 \mathrm{~mol}$. \% could form fibres with high performance. It was also possible to produce the PGF from the PBG with 12 and 15 mol. $\% \mathrm{~B}_{2} \mathrm{O}_{3}$ whilst it was not possible to draw fibre from the MgP-B20 with 20 mol. $\% \mathrm{~B}_{2} \mathrm{O}_{3}$, which was attributed to the high viscosity and unstable meniscus.

Murgatroyd [42] has reported that the success in fibre manufacture was dependant on the strength of chemical bonding in the glass network and it was possible to draw fibre from molten glass continuously if the chemical bonds were strong enough to withstand the stresses from the drawing process. The PGF could be obtained from $\mathrm{PBG}$ with 50 and 55 mol. $\% \mathrm{P}_{2} \mathrm{O}_{5}$, has been confirmed due to the full of $\mathrm{Q}^{2}$ chain structure units with strong bonding, whilst the fibre drawing from glass with 45 mol. $\% \mathrm{P}_{2} \mathrm{O}_{5}$ was unsuccessful due to short average chain length of glass structure with depolymerisation of $\mathrm{Q}^{1}$ units [39, 3].

Saranti et al. [43] reported that addition of $\mathrm{B}_{2} \mathrm{O}_{3}$ was able to alter the dimensionality of the phosphate based glass network via the creation of long chain $\mathrm{Q}^{2}$ species. It was also confirmed by results from other researchers [44-46], who found that glasses doped with $\mathrm{B}_{2} \mathrm{O}_{3}$ presented an increase in chemical durability and thermal stability due to the formation of P-O-B bonds crosslinking long metaphosphate $\mathrm{Q}^{2}$ chains. However, the MgP-B20 glass fibre with 20 mol. $\% \mathrm{~B}_{2} \mathrm{O}_{3}$ presented lower fibre drawing performance when compared to other $\mathrm{MgP}-\mathrm{B}$ glass fibre with lower $\mathrm{B}_{2} \mathrm{O}_{3}$ content.

From the literature, Ahmed et al developed PGF without $\mathrm{B}_{2} \mathrm{O}_{3}$ and $\mathrm{Fe}_{2} \mathrm{O}_{3}, \quad 50 \mathrm{P}_{2} \mathrm{O}_{5}-40 \mathrm{CaO}-5 \mathrm{Na}_{2} \mathrm{O}-$ $-5 \mathrm{Fe}_{2} \mathrm{O}_{3}$ glass and reported the tensile strength and modulus of $456 \mathrm{MPa}$ and $52 \mathrm{GPa}$, respectively. Felfe et al [47] reported tensile strength and modulus of $\mathrm{Fe}_{2} \mathrm{O}_{3}$-containing $\mathrm{PGF} \quad 40 \mathrm{P}_{2} \mathrm{O}_{5}-24 \mathrm{MgO}-16 \mathrm{CaO}-16 \mathrm{Na}_{2} \mathrm{O}-4 \mathrm{~F}_{2} \mathrm{O}_{3}$ were $318 \mathrm{MPa}$ and $73 \mathrm{GPa}$, respectively. Based on their formula, Sharmin et al [15] developed novel formula with $10 \mathrm{~mol} . \% \mathrm{~B}_{2} \mathrm{O}_{3}$ contained and reported $1200 \mathrm{MPa}$ of tensile strength which was close to that of $\mathrm{MgP}-\mathrm{Fe} 10$ $(1253 \mathrm{MPa})$ in this study.

In this study, a trend of increasing fibre strength with increasing $\mathrm{B}_{2} \mathrm{O}_{3}$ or $\mathrm{Fe}_{2} \mathrm{O}_{3}$ content was exhibited in this study. The tensile strength of MgP-Fe fibres was found to increase by $22 \%$ via addition of $\mathrm{Fe}_{2} \mathrm{O}_{3}$ from 6 to 10 mol. \%, whilst MgP-B fibres revealed $4 \%$ improvement on tensile strength when $\mathrm{B}_{2} \mathrm{O}_{3}$ increased from 12 to 15 mol. \%. Similarly, the tensile modulus of the fibre in this study was found to increase with addition of $\mathrm{B}_{2} \mathrm{O}_{3}$ and $\mathrm{Fe}_{2} \mathrm{O}_{3}$.

It was well known that the strength of glass was demonstrated by its average bond strength, which depended on the chemical composition of the glass [48]. The variation of the chemical composition of the glass could affect cross-chemical bonds and change the polymerisation degree of network, thus resulting in an effect on mechanical strength of glass fibre $[49,48]$. Yu et al [50] and Lin et al. [51] investigated iron phosphate glass and found that Fe could act as a network intermediate to replace $\mathrm{P}-\mathrm{O}-\mathrm{P}$ bonds by $\mathrm{P}-\mathrm{O}-\mathrm{Fe}$ bonds and form highly distorted coordination structure (from tetrahedral coordination to octahedral coordination) with increasing $\mathrm{Fe}_{2} \mathrm{O}_{3}$ content. Additionally, it was also confirmed by Lin et al. [51] that addition of iron into phosphate glass network resulted in an increase of fibre tensile strength and modulus. On the other hand, several studies have reported that the addition of $\mathrm{B}_{2} \mathrm{O}_{3}$ to the phosphate glass network can create $\mathrm{B}-\mathrm{O}-\mathrm{P}$ bonds in $\mathrm{BPO}_{4}$ units which are interconnected $\mathrm{BO}_{4}$ and $\mathrm{PO}_{4}$ tetrahedral units 
$[52,45]$. The improvement in mechanical properties of phosphate glass doped with $\mathrm{B}_{2} \mathrm{O}_{3}$ was confirmed by Shah et al. [53] who found an increase in micro-hardness as $\mathrm{P}_{2} \mathrm{O}_{5}$ was substituted with $\mathrm{B}_{2} \mathrm{O}_{3}$ and reported that this was attributed to the formation of stronger P-O-B linkages. The tensile modulus of materials are intrinsic properties and depends on the field strength of the cation and packing density of the oxygen atoms [49]. Thus, it could also explained due to the natural property of boron as a glass network former which made it possible to become part of the glass network via entering into the backbone of the phosphate based glass and increasing the degree of structural connectivity [54-56].

The Weibull modulus of the fibres in this study was reported to range from 8.1 to 10.6. It was suggested that the tensile strength of a series of PGFs should be in a range of 6 and 12, as a low Weibull modulus would introduce uncertainty about the strength of the fibre [57]. Additionally, the Weibull modulus is a widely accepted method to describe the physics of fibre failure, implied that the probability of failure would be low even stress slightly below the normalising value, if the Weibull modulus value was high [58].

During the degradation, the reduction of tensile strength was revealed for $\mathrm{MgP}-\mathrm{Fe} 6, \mathrm{MgP}-\mathrm{Fe} 8$ and $\mathrm{MgP}$ Fe10 with $58 \%, 80 \%$ and $75 \%$, respectively, whilst the decrease of $67 \%$ and $68 \%$ was observed for MgP-B12 and $\mathrm{MgP}-\mathrm{B} 15$ glass fibres. Additionally, no significant variation of the tensile modulus during the degradation period which was confirmed by Cozien-Cazuc et al [59] who carried out degradation of phosphate glass fibres in distilled water at $37^{\circ}$ for 3 days and found there was no significant change in fibre modulus. It was due to the degradation took place from surface of the fibre, not affect the intrinsic change in the glass fibre structure. The both fibres of $\mathrm{MgP}-\mathrm{Fe}$ and $\mathrm{MgP}-\mathrm{B}$ system exhibited a peeling effect of the fibre's outer layer during degradation.

The dissolution rate of $\mathrm{MgP}-\mathrm{Fe}$ glass fibre was observed to decrease $42 \%$ with addition of $\mathrm{Fe}_{2} \mathrm{O}_{3}$ from 6 to $10 \mathrm{~mol}$. \%. Several preliminary studies showed that the addition of $\mathrm{Fe}_{2} \mathrm{O}_{3}$ into phosphate based glass in order to enhance biocompatibility via improve chemical durability $[60,61]$. It was attributed to the replacement of $\mathrm{P}-\mathrm{O}-\mathrm{P}$ bonds in the glass by $\mathrm{Fe}-\mathrm{O}-\mathrm{P}$ bonds and to strong cross-linking of phosphate chains by iron ions. Additionally, Fu et al. [50] suggested that only the form $\mathrm{Fe}$ (III) strengthened the network structure of the glasses more like a network former. However, the status of $\mathrm{Fe}$ in $\mathrm{Fe}(\mathrm{II})$ or $\mathrm{Fe}$ (III) form of $\mathrm{Fe}$ form could not be confirmed in this study yet. Normally, addition of $\mathrm{B}_{2} \mathrm{O}_{3}$ could increase cross-linking and improving chemical durability due to B-O-P linkage forming [26]. However, an increase of $27 \%$ for glass with addition of 12 to $15 \mathrm{~mol}$. \% was observed. It could be attributed to the reduction of $\mathrm{MgO}$ with addition of $\mathrm{B}_{2} \mathrm{O}_{3}$ in the phosphate glass network as $\mathrm{MgO}$ was also potential network former like $\mathrm{B}_{2} \mathrm{O}_{3}$ to cross link glass network and improve chemical durability
[14]. Thus, substitution of $\mathrm{B}_{2} \mathrm{O}_{3}$ for $\mathrm{MgO}$ could result in both positive and negative effects on the glass structure stability and chemical durability. In this case, the glass structure was evidently demonstrated by $\mathrm{MgO}$ when $\mathrm{B}_{2} \mathrm{O}_{3}$ increased from 12 to $15 \mathrm{~mol} . \%$ and resulted in an increase of glass dissolution rate.

Dissolution rate is important for biomaterials on cytocompatibility assessment of biomaterials due to ion release and $\mathrm{pH}$ variation during the biomaterial degradation. Zhu et al. [26] and Sharmin et al. [29] have developed several phosphate based glass system with good cytocompatibility and dissolution rate. When compared to the glass dissolution rate of them, the glass in this study presented lower dissolution rate $(1.03 \times$ $\times 10^{-8} \mathrm{~kg} \cdot \mathrm{m}^{-2} \cdot \mathrm{s}^{-1}$ for glass formula $48 \mathrm{P}_{2} \mathrm{O}_{5}-12 \mathrm{~B}_{2} \mathrm{O}_{3}-$ $-19 \mathrm{MgO}-14 \mathrm{CaO}-1 \mathrm{Na}_{2} \mathrm{O}-6 \mathrm{Fe}_{2} \mathrm{O}_{3}$ ). Potentially, it was expected that the glass fibre system in this study was able to present good cytocompatibilty for medical application. However, the in vitro cytocompatibility study should be taken into account in the future research, to confirm the bioactivity of glass.

\section{CONCLUSION}

Six phosphate based glass formulations were produced and divided to be two glass system $48 \mathrm{P}_{2} \mathrm{O}_{5}-12 \mathrm{~B}_{2} \mathrm{O}_{3}-$ $-(25-\mathrm{X}) \mathrm{MgO}-14 \mathrm{CaO}-1 \mathrm{Na}_{2} \mathrm{O}-(\mathrm{X}) \mathrm{Fe}_{2} \mathrm{O}_{3}(\mathrm{X}=6,8,10)$ and $45 \mathrm{P}_{2} \mathrm{O}_{5}-(\mathrm{Y}) \mathrm{B}_{2} \mathrm{O}_{3}-(32-\mathrm{Y}) \mathrm{MgO}-14 \mathrm{CaO}-1 \mathrm{Na}_{2} \mathrm{O}-8 \mathrm{Fe}_{2} \mathrm{O}_{3}$ ( $\mathrm{Y}=12,15,20)$ for glass fibre drawing, whilst five of them were converted to be fibre successfully. The PBG with 20 mol. $\% \mathrm{~B}_{2} \mathrm{O}_{3}$ was difficult to form fibre with stable meniscus due to high viscosity.

The mechanical properties of fibre was increased with an increase of $\mathrm{B}_{2} \mathrm{O}_{3}$ and $\mathrm{Fe}_{2} \mathrm{O}_{3}$ in the PBG and the $\mathrm{MgP}-\mathrm{Fe} 10$ fibre provided the highest tensile strength $(1253 \pm 92 \mathrm{MPa})$, which was higher than that of PGF in the literature. After degradation study, $20 \sim 40 \%$ tensile strength of fibre was residual whilst no significant change $(\mathrm{P}>0.05)$ in the tensile modulus was observed.

The dissolution rate of fibre was observed to decrease with addition of $\mathrm{Fe}_{2} \mathrm{O}_{3}$ whilst this value was increase with increase content of $\mathrm{B}_{2} \mathrm{O}_{3}$. The peeling effect of the outer layer of fibres during the degradation was observed from day-7.

\section{Acknowledgements}

The authors would like to thank Sinoma Co., Ltd (China) for kindly providing glass fibres for this study. Additionally, authors also would like to appreciate the financial supported by Ningbo S\&T bureau Ningbo International Collaboration Project (project code 2017D10012), and Ningbo 3315 Innovation team Scheme "Composites Development and Manufacturing for Sustainable Environment".

\section{REFERENCE}


1. Malekani J., Schmutz B., Gu Y., Schuetz M., Yarlagadda P. K. (2011). Biomaterials in orthopedic bone plates: a review. in: Proceedings of the $2^{\text {nd }}$ Annual International Conference on Materials Science, Metal \& Manufacturing (M3 2011). Global Science and Technology Forum. pp. 71-77.

2. Malekani J., Schmutz B., Gu Y., Schuetz M., Yarlagadda P. (2014): Orthopedic bone plates: Evolution in Structure, Implementation technique and biomaterial. GSTF Journal of Engineering Technology (JET), 1(1), 135-140.

3. Ahmed I., Lewis M., Olsen I., Knowles J.C. (2004): Phosphate glasses for tissue engineering: Part 2. Processing and characterisation of a ternary-based $\mathrm{P}_{2} \mathrm{O}_{5}-\mathrm{CaO}-\mathrm{Na}_{2} \mathrm{O}$ glass fibre system, Biomaterials, 25, 501-507. doi:10.1016/S01429612(03)00547-7

4. Charles-Harris M., del Valle S., Hentges E., Bleuet P., Lacroix D., Planell J.A. (2007): Mechanical and structural characterisation of completely degradable polylactic acid/calcium phosphate glass scaffolds, Biomaterials, 28, 4429-4438. doi: 10.1016/j.biomaterials.2007.06.029

5. Lee Y.K. and LeGeros R.Z. (2008): Calcium phosphate glass: potential as biomaterial for hard tissue repair, Key Engineering Materials, 377, 43-72. doi: 10.4028/www.scientific.net/KEM. 377.43

6. Parsons A.J., Ahmed I., Haque P., Fitzpatrick B., Niazi M.I.K., Walker G.S., Rudd C.D. (2009): Phosphate glass fibre composites for bone repair, Journal of Bionic Engineering, 6, 318-323. doi: 10.1016/S1672-6529(08)60132-8

7. Haque P., Ahmed I., Parsons A., Felfel R., Walker G., Rudd C. (2013): Degradation properties and microstructural analysis of $40 \mathrm{P} 2 \mathrm{O} 5-24 \mathrm{MgO}-16 \mathrm{CaO}-16 \mathrm{Na}_{2} \mathrm{O}-4 \mathrm{Fe}_{2} \mathrm{O}_{3}$ phosphate glass fibres, Journal of Non-Crystalline Solids, 375, 99-109. doi: 10.1016/j.jnoncrysol.2013.05.008

8. Pazzaglia U.E., Gabbi C., Locardi B., Di Nucci A., Zatti G., Cherubino P. (1989): Study of the osteoconductive properties of bioactive glass fibers. Journal of Biomedical Materials Research, 23, 1289-1297. doi: 10.1002/jbm.820231106

9. Pirhonen E., Niiranen H., Niemelä T., Brink M., Törmälä P. (2006): Manufacturing, mechanical characterization, and in vitro performance of bioactive glass 13-93 fibers. Journal of Biomedical Materials Research Part B: Applied Biomaterials, 77, 227-233. doi: 10.1002/jbm.b.30429

10. Jones J., Clare A. (2012). Bio-glasses: an introduction, Wiley.

11. Franks K., Abrahams I., Knowles J. (2000): Development of soluble glasses for biomedical use Part I: In vitro solubility measurement. Journal of Materials Science: Materials in Medicine, 11, 609-614. doi: 10.1023/A:1008949527695

12. Ramakrishna S., Mayer J., Wintermantel E., Leong K.W. (2001): Biomedical applications of polymer-composite materials a review. Composites Science and Technology, 61, 11891224. doi: 10.1016/S0266-3538(00)00241-4

13. Abou Neel E.A., Ahmed I., Blaker J.J., BismarckA., Boccaccini A.R., Lewis M.P., Nazhat S.N., Knowles J.C. (2005): Effect of iron on the surface, degradation and ion release properties of phosphate-based glass fibres, Acta Biomaterialia. 1, 553-563. doi: 10.1016/j.actbio.2005.05.001

14. Ahmed I., Parsons A., Jones A., Walker G., Scotchford C., Rudd C. (2010): Cytocompatibility and effect of increasing $\mathrm{MgO}$ content in a range of quaternary invert phosphate-based glasses. Journal of Biomaterials Applications, 24, 555-575. doi: $10.1177 / 0885328209102761$

15. Sharmin N., Parsons A.J., Rudd C.D., Ahmed I. (2014): Effect of boron oxide addition on fibre drawing, mechanical properties and dissolution behaviour of phosphate-based glass fibres with fixed 40, 45 and $50 \mathrm{~mol} \% \mathrm{P}_{2} \mathrm{O}_{5}$. Journal of Biomaterials Applications, 29(5), 639-653. doi: 10.1177/
0885328214539824

16. Carta D., Qiu D., Guerry P., Ahmed I., Abou Neel E.A., Knowles J.C., Smith M.E., Newport R.J. (2008): The effect of composition on the structure of sodium borophosphate glasses. Journal of Non-Crystalline Solids, 354, 3671-3677. doi: 10.1016/j.jnoncrysol.2008.04.009

17. Qiu D., Guerry P., Ahmed I., Pickup D.M., Carta D., Knowles J.C., Smith M.E., Newport R.J. (2008): A high-energy X-ray diffraction, 31P and 11B solid-state NMR study of the structure of aged sodium borophosphate glasses. Materials Chemistry and Physics, 111, 455-462. doi: 10.1016/j. matchemphys.2008.04.045

18. Gaylord S., Tincher B., Petit L., Richardson K. (2009): Viscosity properties of sodium borophosphate glasses. Materials Research Bulletin, 44, 1031-1035. doi: 10.1016/j.materresbull.2008.11.002

19. Abo-Naf S.M., Khalil E.-S.M., El-Sayed E.-S.M., Zayed H.A., Youness R.A. (2015): In vitro bioactivity evaluation, mechanical properties and microstructural characterization of $\mathrm{Na}_{2} \mathrm{O}-\mathrm{CaO}-\mathrm{B}_{2} \mathrm{O}_{3}-\mathrm{P}_{2} \mathrm{O}_{5}$ glasses. Spectrochimica Acta Part A: Molecular and Biomolecular Spectroscopy, 144, 88-98. doi: 10.1016/j.saa.2015.02.076

20. Harada T., In H., Takebe H., Morinaga K. (2004): Effect of $\mathrm{B}_{2} \mathrm{O}_{3}$ addition on the thermal stability of barium phosphate glasses for optical fiber device. Journal of the American Ceramic Society, 87, 408-411. doi: 10.1111/j.1551-2916.2004.00408.x

21. Karabulut M., Yuce B., Bozdogan O., Ertap H. and Mammadov G.M. (2011): Effect of boron addition on the structure and properties of iron phosphate glasses. Journal of Non-Crystalline Solids, 357, 1455-1462. doi: 10.1016/j. jnoncrysol.2010.11.023

22. Massera J., Claireaux C., Lehtonen T., Tuominen J., Hupa L. and Hupa M. (2011): Control of the thermal properties of slow bioresorbable glasses by boron addition, Journal of Non-Crystalline Solids, 357, 3623-3630. doi: 10.1016/j. jnoncrysol.2011.06.037

23. Ahmed I., Parsons A., Liu J. and Rudd C.D. (2012). Phosphate-based glass fibres: applications within heathcare, in: Proceedings of International Glass Fiber Symposium, NRW, Germany.

24. Parsons A.J., Ahmed I., Han N., Felfel R., Rudd C.D. (2010): Mimicking bone structure and function with structural composite materials. Journal of Bionic Engineering, 7, S1-S10. doi: 10.1016/S1672-6529(09)60211-0

25. Ahmed I., Jones I., Parsons A., Bernard J., Farmer J., Scotchford C., Walker G., Rudd C. (2011): Composites for bone repair: phosphate glass fibre reinforced PLA with varying fibre architecture. Journal of Materials Science: Materials in Medicine, 22, 1825-1834. doi: 10.1007/s10856-011-4361-0

26. Zhu C., Ahmed I., Parsons A., Hossain K.Z., Rudd C., Liu J. and Liu X. (2017): Structural, thermal, in vitro degradation and cytocompatibility properties of $\mathrm{P}_{2} \mathrm{O}_{5}-\mathrm{B}_{2} \mathrm{O}_{3}-\mathrm{CaO}-\mathrm{MgO}-$ $-\mathrm{Na}_{2} \mathrm{O}-\mathrm{Fe}_{2} \mathrm{O}_{3}$ glasses. Journal of Non-Crystalline Solids, 457, 77-85. doi: 10.1016/j.jnoncrysol.2016.11.001

27. Zhu C., Ahmed I., Parsons A., Wang Y., Tan C., Liu J., Rudd C. and Liu X. (2017): Novel bioresorbable phosphate glass fiber textile composites for medical applications, Polymer Composites, doi: 10.1002/pc.24499

28. Yuan G., Zhang T. and Inoue A. (2003): Thermal stability, glass-forming ability and mechanical properties of Mg-Y-Zn$\mathrm{Cu}$ glassy alloys. Materials Transactions, 44, 2271-2275. doi: 10.2320/matertrans. 44.2271

29. Sharmin N., Hasan M.S., Parsons A.J., Furniss D., Scotchford C.A., Ahmed I., Rudd C.D. (2013): Effect of boron addition on the thermal, degradation, and cytocompatibility properties of phosphate-based glasses. BioMed Research International, 
2013, 1-12. doi:10.1155/2013/902427

30. Lim J.W., Schmitt M.L., Brow R.K., Yung S.W. (2010): Properties and structures of tin borophosphate glasses. Journal of Non-Crystalline Solids, 356, 1379-1384. doi: 10.1016/j. jnoncrysol.2010.02.019

31. Sharmin N., Rudd C.D., Parsons A.J., Ahmed I. (2016): Structure, viscosity and fibre drawing properties of phosphatebased glasses: effect of boron and iron oxide addition. Journal of Materials Science, 51, 7523-7535. doi: 10.1007/s10853016-0032-3

32. British Standards Institution, BS 10119, 2002 (2002), London.

33. British Standards Institution, BS 10993-13, 2010 (2010), London.

34. British Standards Institution, BS 11566, 1996 (1996), London.

35. Andersons J., Joffe R., Hojo M., Ochiai S. (2002): Glass fibre strength distribution determined by common experimental methods. Composites Science and Technology, 62, 131-145. doi: 10.1016/S0266-3538(01)00182-8

36. Ahmed I., Parsons A.J., Palmer G., Knowles J.C., Walker G.S., Rudd C.D. (2008): Weight loss, ion release and initial mechanical properties of a binary calcium phosphate glass fibre/PCL composite. Acta Biomaterialia, 4, 1307-1314. doi: 10.1016/j.actbio.2008.03.018

37. Wang Y., Chan Y.C., Gui Z.L., Webb D.P., Li L.T. (1997): Application of Weibull distribution analysis to the dielectric failure of multilayer ceramic capacitors. Materials Science and Engineering B, 47, 197-203. doi: 10.1016/S0921-5107 (97)00041-X

38. Abou Neel E.A., Young A.M., Nazhat S.N., Knowles J.C. (2007): A facile synthesis route to prepare microtubes from phosphate glass fibres. Advanced Materials, 19, 2856-2862. doi: 10.1002/adma.200700039

39. Ahmed I., Lewis M., Olsen I., Knowles J.C. (2004): Phosphate glasses for tissue engineering: Part 1 . Processing and characterisation of a ternary-based $\mathrm{P}_{2} \mathrm{O}_{5}-\mathrm{CaO}-\mathrm{Na}_{2} \mathrm{O}$ glass system., Biomaterials, 25, 491-499. doi: 10.1016/S01429612(03)00546-5

40. LeGeros R., Legeros J. (1984). Phosphate Minerals, Springer Berlin Heidelberg.

41. Cao W., Hench L.L. (1996): Bioactive materials. Ceramics International, 22, 493-507. doi: 10.1016/0272-8842(95) 00126-3

42. Murgatroyd J.B. (1948): The delayed elastic effect in glass fibres and the constitution of glass in fibre form. Journal of the Society of Glass Technology, 32, 291-300.

43. Saranti A., Koutselas I. and Karakassides M.A. (2006): Bioactive glasses in the system $\mathrm{CaO}-\mathrm{B}_{2} \mathrm{O}_{3}-\mathrm{P}_{2} \mathrm{O}_{5}$ : Preparation, structural study and in vitro evaluation. Journal of NonCrystalline Solids, 352, 390-398. doi: 10.1016/j.jnoncrysol. 2006.01.042

44. Baikova L.G., Fedorov Y.K., Pukh V.P., Tikhonova L.V., Kazannikova T.P., Sinani A.B. and Nikitina S.I. (2003): Influence of boron oxide on the physicomechanical properties of glasses in the $\mathrm{Li}_{2} \mathrm{O}-\mathrm{B}_{2} \mathrm{O}_{3}-\mathrm{P}_{2} \mathrm{O}_{5}$ system. Glass Physics and Chemistry, 29, 276-281. doi: 10.1023/A:1024486116145

45. Kim N.-J., Im S.-H., Kim D.-H., Yoon D.-K. and Ryu B.-K. (2010): Structure and properties of borophosphate glasses. Electronic Materials Letters, 6, 103-106. doi: 10.3365/eml. 2010.09.103

46. Tho T.D., Prasada Rao R. and Adams S. (2012): Structure property correlation in lithium borophosphate glasses. The European Physical Journal E, 35, 1-11. doi: 10.1140/epje/ i2012-12008-y

47. Felfel R.M., Ahmed I., Parsons A.J. and Rudd C.D. (2013): Bioresorbable screws reinforced with phosphate glass fibre: manufacturing and mechanical property characterisation.
Journal of the Mechanical Behavior of Biomedical Materials, 17, 76-88. doi: 10.1016/j.jmbbm.2012.08.001

48. Nishikubo Y., Yoshida S., Sugawara T.,Matsuoka J. (2011), Intrinsic strength of sodium borosilicate glass fibers by using a two-point bending technique, in: IOP Conference Series: Materials Science and Engineering. IOP Publishing. Vol. 18, No. 11, p. 112019.

49. Baikova L., Fedorov Y.K. and Tolstoi M. (1990): Structural strength of phosphate glasses. Glass Physics and Chemistry, 16, 384-391.

50. Yu X.Y., Day D.E., Long G.J. and Brow R.K. (1997): Properties and structure of sodium-iron phosphate glasses. Journal of Non-Crystalline Solids, 215, 21-31. doi: 10.1016/ S0022-3093(97)00022-7

51. Lin S.T., Krebs S.L., Kadiyala S., Leong K.W., LaCourse W.C. and Kumar B. (1994): Development of bioabsorbable glass fibres, Biomaterials, 15, 1057-1061. doi: 10.1016/01429612(94)90091-4

52. Koudelka L. and Mošner P. (2000): Borophosphate glasses of the $\mathrm{ZnO}-\mathrm{B}_{2} \mathrm{O}_{3}-\mathrm{P}_{2} \mathrm{O}_{5}$ system. Materials Letters, 42, 194-199. doi: 10.1016/S0167-577X(99)00183-4

53. Shah K.V., Goswami M., Deo M.N., Sarkar A., Manikandan S., Shrikhande V.K. and Kothiyal G.P. (2006): Effect of $\mathrm{B}_{2} \mathrm{O}_{3}$ addition on microhardness and structural features of $40 \mathrm{Na}_{2} \mathrm{O}$ $10 \mathrm{BaO}-\mathrm{xB}_{2} \mathrm{O}_{3}-(50-\mathrm{x}) \mathrm{P}_{2} \mathrm{O}_{5}$ glass system. Bulletin of Materials Science, 29, 43-48.

54. Pukh V.P., Baikova L.G., Kireenko M.F., Tikhonova L.V., Kazannikova T.P. and Sinani A.B. (2005): Atomic structure and strength of inorganic glasses, Physics of the Solid State, 47, 876-881. doi: $10.1134 / 1.1924848$

55. Raskar D., Rinke M.T. and Eckert H. (2008): The MixedNetwork Former Effect in Phosphate Glasses: NMR and XPS Studies of the Connectivity Distribution in the Glass System $\left(\mathrm{NaPO}_{3}\right)_{1-\mathrm{x}}\left(\mathrm{B}_{2} \mathrm{O}_{3}\right)_{\mathrm{x}}$. The Journal of Physical Chemistry C, 112, 12530-12539. doi: 10.1021/jp8035549

56. Rinke M.T. and Eckert H. (2011): The mixed network former effect in glasses: solid state NMR and XPS structural studies of the glass system $\left(\mathrm{Na}_{2} \mathrm{O}\right) \mathrm{x}\left(\mathrm{BPO}_{4}\right)_{1-\mathrm{x}}$. Physical Chemistry Chemical Physics, 13, 6552-6565. doi: 10.1039/C0CP01590C

57. Karabulut M., Melnik E., Stefan R., Marasinghe G.K., Ray C.S., Kurkjian C.R. and Day D.E. (2001): Mechanical and structural properties of phosphate glasses. Journal of NonCrystalline Solids, 288, 8-17. doi: 10.1016/S0022-3093(01) 00615-9

58. Parsons A.J., Ahmed I., Yang J., Cozien-Cazuc S., Rudd C.D. (2007) Heat-treatment of phosphate glass fibres and its effect on composite property retention, in: $16^{\text {th }}$ International Conference on Composite Materials. Kyoto.pp.1-7.

59. Cozien-Cazuc S., Parsons A.J., Walker G.S., Jones I.A., Rudd C.D. (2008): Effects of aqueous aging on the mechanical properties of $\mathrm{P}_{40} \mathrm{Na}_{20} \mathrm{Ca}_{16} \mathrm{Mg}_{24}$ phosphate glass fibres. Journal of Materials Science, 43, 4834-4839. doi: 10.1007/s10853008-2698-7

60. Concas G., Congiu F., Manca E., Muntoni C., Pinna G. (1995): Mossbauer spectroscopic investigation of some iron-containing sodium phosphate glasses. Journal of NonCrystalline Solids, 192-193, 175-178. doi: 10.1016/00223093(95)00347-9

61. Dey K., Sharmin N., Khan R.A., Nahar S., Parsons A.J., Rudd C.D. (2011): Effect of Iron Phosphate Glass on the Physicomechanical Properties of Jute Fabric-reinforced Polypropylene-based Composites. Journal of Thermoplastic Composite Materials, 24, 695-711. doi:10.1177/0892705711401848 